Theater Enough

\&fo 



\title{
Theater Enough
}

\section{American Culture}

\author{
and the Metaphor of
}

the World Stage,

$$
\text { offe }
$$

J EF F R E Y H. R I C H A R D S

D UKE UN IVER S I T Y PRESS

Durham and London, 1991 
(C) 1991 Duke University Press

All rights reserved

Printed in the United States of America

on acid-free paper $\infty$

Library of Congress Cataloging-in-Publication Data appear on the last page of this book. 
For Ann Dennis

and George Ariffe 
